\title{
AsesmenCarbon Footprint pada Produksi Minyak Kelapa Sawit (Elaeis guineensis Jacq.) di Kebun Sei Lukut, Kabupaten Siak, Riau
}

Carbon Footprint Assessment of Palm Oil Production in Sei Lukut Estate, Siak District, Riau

\section{Rizka Tri Arjuna dan Edi Santosa*}

Departemen Agronomi dan Hortikultura, Fakultas Pertanian, Institut Pertanian Bogor Jalan Meranti, Kampus IPB Dramaga, Bogor 16680, Indonesia Telp.\& Faks.62-251-8629353 e-mail: agronipb@ indo.net.id

*Penulis untuk korespondensi : edisang@gmail.com

Disetujui 14 Mei 2018 / Published online 21 Mei 2018

\begin{abstract}
Indonesia is the largest exporter of crude palm oil from oil palm tree (Elaeis guineensis Jacq.) in the world. Some importers like EU and US require clean production management on oil palm as indicated by sustainable production. Carbon footprint has been used as indicator in sustainable production of many crops, however, carbon footprint is rarely evaluated in oil palm plantation in Indonesia. This research aimed to evaluate annual carbon footprint in CPO production. Activity was conducted at Sei Lukut Estate, Siak District, Riau Province from March to June 2016. Carbon foorprint evaluation included plantation area, fertilizer application, electricity generator, lighting, fuel for transportation, and electricity in palm oil milling factory. The results showed that the estate had applied good production management. Carbon footprint from one liter of CPO was $9.55 \mathrm{~kg}$.
\end{abstract}

Keywords: Cabon emission, Elaeis guineensis, plantation management,oil palm, sustainable production.

\begin{abstract}
ABSTRAK
Jejak karbon telah digunakan sebagai indikator dalam produksi yang berkelanjutan pada banyak tanaman, namun jejak karbon jarang dievaluasi pada pertanaman kelapa sawit di Indonesia. Kegiatan penelitian bertujuan untuk mengevaluasi jejak karbon tahunan pada produksi minyak kelapa sawit. Kegiatan dilaksanakan di kebun Sei Lukut, Kabupaten Siak, Provinsi Riau dari Maret sampai Juni 2016. Evaluasi pada jejak karbon mencakup kegiatan budidaya, pengolahan TBS di PKS, dan kegiatan rumah tangga. Lokasi studi telah mengaplikasikan manajemen produksi yang baik. Hasil pengamatan menunjukkan bahwa jejak karbon dari satu liter CPO adalah 9,55 kg.
\end{abstract}

Kata Kunci: Elaeis guineensis, emisi karbon, kelapa sawit manajemen produksi, produksi berkelanjutan. 


\section{PENDAHULUAN}

Data luas areal pertanaman kelapa sawit terus meningkat; menurut Direktorat Jenderal Perkebunan (2016) luas perkebunan selama sepuluh tahun terakhir menunjukkan peningkatan dari 6,59 juta ha pada tahun 2006 menjadi 11,3 juta ha pada 2015. Total produksi menurut Direktorat Jenderal Perkebunan (2016) adalah 31,28 juta ton minyak sawit, atau produktivitas rata-rata mencapai 3,68 ton ha $^{-1}$. Hal tersebut menjadikan Indonesia menjadi negara pengekspor terbesar di dunia.

Minyak sawit mentah (crude palm oil CPO) dapat diolah menjadi berbagai produk turunan seperti minyak goreng, mentega, sabun, kosmetik, dan obat. Selain itu minyak kelapa sawit dapat menjadi subsitusi bahan bakar minyak yang saat ini sebagian besar dipenuhi dari minyak bumi (Setyamidjaja, 2006). Hal itu menyebabkan beberapa negara pembuat produk tersebut tertarik untuk mengimpor minyak kelapa sawit. Evri (2012) menyatakan bahwa ekspor CPO Indonesia ke negara Eropa dan Amerika terganjal isu lingkungan, khususnya adanya tuduhan bahwa produksi CPO merupakan sumber pelepasan karbon. Pelepasan karbon tersebut terjadi dalam proses penanaman dan proses industri pengolahan buah sawit. Hal ini berdampak pada kebijakan Uni Eropa dan USA yang mensyaratkan CPO jika dikategorikan sebagai bahan bakar nabati (biofuel) harus mampu menyimpan karbon sebesar 35\% dibandingkan dengan bahan bakar fosil. Namun demikian, kajian terkait dengan emisi karbon pada perkebunan kelapa sawit di Indonesia masih terbatas.

Perhitungan emisi karbon dari proses industri dan perkebunan dapat dilakukan secara langsung dan secara tidak langsung. Perhitungan secara langsung membutuhkan waktu dan sumberdaya yang besar, oleh karena itu perhitungan secara tidak langsung lebih banyak digunakan. Salah satu cara mengukur tingkat emisi karbon secara tidak langsung adalah dengan pendekatan carbon footprint (jejak karbon). Sugiyanto (2013) menyatakan bahwa carbon footprint adalah jumlah emisi karbon yang dilepaskan dalam kegiatan memproduksi per periode tertentu. Pengetahuan terhadap proses produksi dan emisi yang dihasilkan pada setiap proses produksi CPO sangat diperlukan.

Khusus pada industri pertanian, jejak karbon memiliki cakupan yakni (1) menghitung emisi karbon berupa $\mathrm{CO}_{2}$, (2) setiap usaha pertanian mempunyai jejak karbon yang khas, (3) perhitungan jejak karbon mempertimbangkan tata guna lahan, dan (4) menghitung nilai emisi karbon setiap satuan produk sehingga dapat meningkatkan daya saing ekspor.
Jejak karbon pada produksi minyak kelapa sawit mencakup emisi karbon yang dihasilkan dari kegiatan produksi untuk setiap satu liter CPO. Emisi karbon tersebut merupakan total emisi karbon yang dihasilkan selama kegiatan produksi dikurangi dengan karbon yang diserap oleh tanaman kelapa sawit (carbon sequestration). Perhitungan jejak karbon itu sendiri dipengaruhi oleh kegiatan budidaya, pengolahan di PKS hingga kegiatan rumah tangga. Tujuan penelitian adalah menghitung carbon footprint dari mulai kegiatan budidaya, pengolahan di pabrik kelapa sawit hingga kegiatan rumah tangga. Harapannya, kegiatan produksi $\mathrm{CPO}$ dapat mengurangi sumber emisi karbon.

\section{METODE}

Studi dilaksanakan di PT. Surya Intisari Raya-Lukut, First Resources Group, Kabupaten Siak, Provinsi Riau selama empat bulan yaitu bulan Maret sampai Juni 2016.

Data juga diperoleh dari pengamatan langsung di lapangan, diskusi, dan wawancara dengan pihak kebun. Data diperoleh dari laporan manajemen perusahaan meliputi keadaan tanah dan iklim, luas areal dan tata guna lahan, kondisi tanaman dan produksi dan norma ketenagakerjaan perusahaan.

Secara khusus, sumber emisi karbon diidentifikasi, dan besar nilai emisinya dihitung berdasarkan nilai konversi, referensi pustaka, pengambilan sampling atau melalui wawancara. Pada tahap berikutnya adalah menghitung neraca karbon dari sejak kegiatan budidaya hingga dihasilkan CPO. Emisi karbon utama berasal dari kegiatan lansung seperti pemupukan, pembakaran bensin/solar/bahan bakar lain pada transportasi dan pembangkit listrik, dan kegiatan rumah tangga. Estimasi emisi $\mathrm{CO}_{2}$ dari konsumsi energi diperoleh dari hasil kali antara volume penggunaan energi (misalnya, $\mathrm{kWh}$ listrik, liter bahan bakar) dengan faktor emisi $\mathrm{CO}_{2}$ rata-rata ( $\mathrm{kg} \mathrm{CO} / \mathrm{kWh}$ ). Semua perhitungan adalah basis satu tahun, sehingga hasilnya adalah jejak karbon tahunan. Jejak karbon dari proses pembuatan material, alat dan peralatan serta pembangunan kebun tidak dilakukan perhitungan dalam penelitian ini.

Indofood Agri Resources LTD melalui Sustainability Report (2014), menunjukkan bahwa alur jejak karbon yang penting dalam kebun diklasifikasikan menjadi 3 titik yaitu, kegiatan dalam pertanaman kelapa sawit, transportasi Tandan Buah Segar (TBS) menuju Pabrik Kelapa 
Sawit (PKS), dan kegiatan dalam pengolahan TBS menjadi CPO di PKS. Kegiatan yang termasuk dalam pertanaman kelapa sawit adalah emisi karbon akibat penguapan lahan mineral dan gambut $\left(\mathrm{CO}_{2}\right.$ ton ha $\left.{ }^{-1} \operatorname{tahun}^{-1}\right)$, respirasi tanaman $\left(\mathrm{CO}_{2}\right.$ ton ha $^{-1}$ tahun $\left.^{-1}\right)$, emisi karbon dari komsumsi bahan bakar, dan emisi karbon dari konsumsi listrik untuk perumahan, peribadatan, dan perkantoran $\left(\mathrm{CO}_{2}\right.$ ton $\mathrm{ha}^{-1}$ tahun $\left.^{-1}\right)$. Data sumber karbon dari transportasi pengankutan TBS dari kebun ke PKS adalah konsumsi solarnya $\left(\mathrm{CO}_{2}\right.$ ton ha ${ }^{-1}$ tahun $\left.^{-1}\right)$. Pabrik kelapa sawit juga memiliki sumber karbon yaitu solar yang dikonsumsi pabrik, dan listrik yang dikonsumsi pabrik $\left(\mathrm{CO}_{2}\right.$ ton $\mathrm{ha}^{-1}$ tahun $\left.^{-1}\right)$. Dengan demikian, penelitian ini lebih bersifat asesmen dalam satu rangkaian proses produksi selama waktu asesmen terutama tahunan secara agregat.

Perhitungan nilai $\mathrm{CO}_{2}$ yang menjadi emisi dari penggunaan energi dapat dilakukan dengan cara pendekatan sektoral atau referensi (Kementerian Lingkungan Hidup, 2012).
Pendekatan yang digunakan dalam perhitungan emisi kendaraan dan konsumsi listrik adalah pendekatan referensi yaitu dengan cara menghitung jumlah konsumsi bahan bakar dan konsumsi listrik dalam satu satuan waktu tertentu kemudian dikalikan dengan masing-masing faktor konversinya.

\section{HASIL DAN PEMBAHASAN}

\section{Produksi}

Jenis tanaman kelapa sawit yang ditanam adalah tenera (DxP Marihat dan DxP PNG) dengan jarak tanam $9,85 \mathrm{~m} \times 9,85 \mathrm{~m} \times 8 \mathrm{~m}$ (segitiga sama kaki), sehingga populasi per hektar adalah 135 pohon. Tahun tanam terdiri dari 9 tahun tanam yaitu 1995, 1996, 1997, 1998, 2003, 2004, 2005, 2009, dan 2010. Produksi dan produktivitas TBStahunan dapat dillihat pada Tabel

Tabel 1. Produksi dan produktivitas kelapa sawit di Kebun Sei Lukut 6 tahun terakhir

\begin{tabular}{lccc}
\hline Tahun & Luas (ha) & Produksi TBS (ton) & Produktivitas TBS (ton ha $^{-1}$ ) \\
\hline 2010 & $4.307,47$ & $88.501,16$ & 20,55 \\
2011 & $4.272,26$ & $100.228,59$ & 23,46 \\
2012 & $4.322,70$ & $102.327,38$ & 23,62 \\
2013 & $4.357,91$ & $101.486,17$ & 23,29 \\
2014 & $4.357,91$ & $101.706,73$ & 23,34 \\
2015 & $4.357,91$ & $105.732,46$ & 24,26 \\
\hline
\end{tabular}

\section{Emisi karbon}

Emisi karbon adalah karbon yang dilepaskan untuk menghasilkan sesuatu pada periode tertentu tanpa melihat pengaruh serapan atau penggunaan karbonnya. Emisi karbon pada produksi minyak kelapa sawit di lokasi terdeteksi pada jenis lahan, konsumsi solar, konsumsi listrik, bahan bakar rumah tangga, pemupukan, dan limbah dari hasil pengolahan TBS menjadi CPO. Perhitungan seluruh emisi yang dihasilkan merupakan akumulasi emisi selama setahun pada masing-masing kegiatan.

Jenis lahan menentukan perbedaan emisi karbon (Tabel 2). Hasil penelitian Hadiwijaya et al. (2014) menunjukkan bahwa asimilasi di agrosistem perkebunan kelapa sawit di lahan mineral sebesar 175 ton $\mathrm{CO}_{2}$ ha $^{-1}$ tahun $^{-1}$ sebagai gross primary production (GPP) dan mengemisikan 70 ton $\mathrm{CO}_{2}$ ton ha ${ }^{-1}$ tahun $^{-1}$ sebagai respirasi dari tanah mineral. Sementara itu, hasil penelitian Hooijer et al., (2012) menggunakan metode subsiden pada lahan gambut menunjukkan nilai emisi 78 ton $\mathrm{CO}_{2}$ ha $^{-1}$ tahun $^{-1}$. Dengan demikian, lahan gambut mengemisikan $\mathrm{CO}_{2}$ lebih besar dibandingkan dengan lahan mineral. Emisi $\mathrm{CO}_{2}$ dari lahan gambut dapat meningkat jika pemeliharaan lahan gambut tidak dikelola dengan benar (Nusantara et al., 2014).

Pengelolaan gambut yang baik adalah dengan cara mengendalikan faktor yang dapat mempengaruhi emisi $\mathrm{CO}_{2}$ yaitu kedalaman muka air tanah (Couwenberg, 2009). Penurunan kedalaman air tanah menyebabkan kondisi permukaan tanah gambut semakin aerob. Kondisi tersebut dapat meningkatkan aerasi dalam tanah, sehingga karbon di lahan gambut semakin mudah teroksidasi oleh aktivitas mikroba tanah (Hirano et al., 2012). Pengamatan kedalaman muka air tanah pada blok H10, H11, I10, dan I11 di Kebun Sei Lukut menggunakan alat ukur ketinggian air drainase yang dipasang secara permanen. Alat ukur tersebut berfungsi sebagai tolak ukur keadaan permukaan air dalam batas yang tidak berpotensi menyebabkan gambut mudah terbakar karena kekeringan dan berpotensi meningkatkan emisi $\mathrm{CO}_{2}$. Kedalaman muka air tanah yang optimum pada kegiatan budidaya kelapa sawit berada diantara 40-60 cm (Winarna et al., 2015) atau 60-85 cm (Page et al., 2010) dari permukaan tanah.

Alat ukur tersebut diletakkan pada setiap sudut drainase batas antar blok di areal lahan gambut. 
Alat ukur tidak tersedia pada seluruh blok lahan gambut. Hal tersebut dikarenakan patok hilang pada saat banjir dan belum ada upaya untuk mengganti alat ukur yang hilang tersebut. Selain faktor kedalaman muka air tanah, faktor lainnya adalah suhu tanah, iklim (Hirano et al., 2012), konsentrasi nutrisi tanah gambut (Berglund and Burglund, 2011), dan kesuburan tanah gambut (Ojanen et al., 2013).

Tabel 2. Data emisi karbon dioksida berdasarkan jenis lahan selama setahun

\begin{tabular}{|c|c|c|c|}
\hline Jenis Lahan & Luas (ha) & Emisi $\mathrm{CO}_{2}\left(\text { ton ha }^{-1} \operatorname{tahun}^{-1}\right)^{\mathrm{a}}$ & Total emisi $\mathrm{CO}_{2}\left(\right.$ ton tahun $\left.{ }^{-1}\right)$ \\
\hline Mineral & $2.864,85$ & 70 & $200.539,50$ \\
\hline Gambut & $1.493,06$ & 78 & $116.458,68$ \\
\hline Total & $4.357,91$ & & $316.998,18$ \\
\hline
\end{tabular}

Keterangan $\quad$ : ${ }^{a}$ Emisi tanah mineral berdasarkan Hadiwijaya et al. (2014) dan tanah gambut berdasarkan Hooijer et al. (2012)

Total $\mathrm{CO}_{2}$ yang dihasilkan dari transportasi adalah 499,72 ton tahun ${ }^{-1}$. Nilai tersebut merupakan penjumlahan dari total $\mathrm{CO}_{2}$ dari kendaraan pengangkut TBS dari lokasi panen menuju TPH, pengangkut TBS dari TPH menuju ke PKS, pengangkut limbah tandan kosong, pengangkut tim unit semprot (TUS), operasional alat berat, dan kendaraan penumpang (operasional staf, bus sekolah ambulans) sebagai penunjang dan pelengkap kegiatan produksi. Selain untuk transportasi, bahan bakar solar juga digunakan untuk pembangkit listrik tenaga diesel (PLTD) atau genset sebagai penunjang kegiatan produksi di perumahan, kantor karyawan, dan genset PKS.

Konsumsi solar yang cukup banyak pada mesin genset menjadi pertimbangan kebun dalam mengaplikasikan sistem nyala-padam dalam sehari. Total $\mathrm{CO}_{2}$ yang dihasilkan oleh genset perumahan dan kantor adalah 212,97 ton tahun ${ }^{-1}$ dan Genset PKS adalah 167,80 ton tahun ${ }^{-1}$ (Tabel 3). Menghitung nilai $\mathrm{CO}_{2}$ yang menjadi emisi dari penggunaan energi dapat dilakukan dengan cara pendekatan sektoral atau referensi (Kementerian Lingkungan Hidup, 2012), berdasarkan jumlah konsumsi bahan bakar. Hal ini menunjukkan bahwa jenis mesin dan jarak tempuh tidak menjadi faktor penentu dalam perhitungan emisi yang digunakan. Nilai total emisi $\mathrm{CO}_{2}$ didapatkan dari hasil perkalian jumlah konsumsi bahan bakar dalam waktu satu tahun dengan faktor konversi bahan bakar solar (DEFRA, 2010).

Konsumsi solar telah dikurangi dengan mengganti beberapa mesin yang belum menggunakan sistem injeksi menjadi mesin yang menggunakan sistem injeksi. Kendaran dengan sistem injeksi dalam proses pembakarannya mengkonsumsi bahan bakar lebih hemat dibandingkan dengan mesin yang belum menggunakan sistem injeksi (Nugraha dan Suprianto, 2007). Kendaraan jenis merupakan upaya lain untuk mengurangi jumlah emisi karbon $\mathrm{CO}_{2}$ pada proses produksi minyak kelapa sawit di lokasi studi.

Tabel 3. Data emisi karbon dioksida berdasarkan konsumsi solar selama setahun

\begin{tabular}{lccc}
\hline Sumber Penggunaan Solar & Jumlah solar (l) & Faktor konversi $\mathrm{CO}_{2}\left(\mathrm{~kg} \mathrm{l}^{-1}\right)^{\mathrm{a}}$ & Jumlah CO $_{2}$ (ton) \\
\hline Transportasi & 189.195 & 26,413 & 499,72 \\
Genset Perumahan & 80.629 & 26,413 & 212,97 \\
Genset PKS dan Perkantoran & 63.528 & 26,413 & 167,80 \\
\hline Total & 333.352 & & 880,49 \\
\hline
\end{tabular}

Keterangan : ${ }^{\mathrm{a}}$ Faktor konversi yang diperoleh dari DEFRA (2010)

Energi listrik merupakan kebutuhan rumah tangga dan kegiatan perkantoran dalam suatu perusahaan. Penggunaan energi listrik perlu dikendalikan karena merupakan salah satu penyumbang $\mathrm{CO}_{2}$ dalam jumlah yang banyak selama kegiatan produksi. Jumlah emisi $\mathrm{CO}_{2}$ dari konsumsi energi listrik adalah 2.624,14 ton (Tabel 4). Konsumsi listrik rata-rata rumah tangga menurut Palaloi (2014) adalah 142,71 kWh bulan 1 . Jumlah rumah yang tersedia di perusahaan adalah 546 unit. Jumlah $\mathrm{CO}_{2}$ tersebut didapatkan dari hasil perkalian jumlah konsumsi (watt tahun ${ }^{-}$
${ }^{1}$ ) dengan faktor konversi listriknya yaitu 0,53936 $\mathrm{kg} \mathrm{kWh}^{-1}$ (DEFRA, 2010).

Pabrik kelapa sawit adalah tempat untuk mengolah TBS menjadi CPO dan KPO. Beberapa mesin yang digunakan untuk proses pengolahan TBS dapat menghasilkan emisi karbon yaitu Turbin 1 dan Turbin 2, Genset 1, Genset 2, dan Genset 3. Emisi karbon dari boiler dinyatakan dalam bentuk $\mathrm{CO}_{2}$ karena untuk menghitung jejak karbon dari turbin dan genset adalah dengan menjumlahkan hasil perkalian konsumsi listrik $(\mathrm{kWh})$ dalam kurun waktu satu tahun dengan faktor konversi listrik (DEFRA, 2010). 
Ada dua upaya yang dapat diterapkan untuk mengurangi jumlah pemakaian arus listrik yang berimplikasi pada pengurangan emisi $\mathrm{CO}_{2}$. Pertama, lamanya nyala-padam dan jumlah peralatan elektronik rumah tangga dan perkantoran seperti lampu, TV, kulkas, dan peralatan elektronik lainnya yang digunakan dalam satu satuan waktu (Widhi dan Hermana, 2013). Kedua, penggunaan jenis dalam alat elektronik yang sama juga berpengaruh pada emisi $\mathrm{CO}_{2}$ (Anggono dan Ahadi, 2015).

Tabel 4. Data emisi karbon dioksida berdasarkan komsumsi listrik selama setahun

\begin{tabular}{lccc}
\hline Sumber Pengguna Listrik & Jumlah listrik $(\mathrm{kWh})$ & $\begin{array}{c}\text { Faktor konversi } \mathrm{CO}_{2}(\mathrm{~kg} \\
\left.\mathrm{kWh}^{-1}\right)^{\mathrm{a}}\end{array}$ & Jumlah $\mathrm{CO}_{2}$ (ton) \\
\hline Perumahan & $935.035,92$ & 0,53936 & 504,32 \\
PKS dan Perkantoran & $3.930 .259,00$ & 0,53936 & $2.119,82$ \\
\hline Total & $4.865 .294,92$ & & $2.624,14$ \\
\hline Keterangan : ${ }^{\mathrm{a}}$ Faktor konversi diperoleh dari DEFRA (2010) & &
\end{tabular}

Selain penggunaan listrik dan bahan bakar solar, kegiatan perumahan lainnya yang dapat mengemisikan karbon adalah penggunaan liquefied petroleum gas (LPG), minyak tanah, dan premium. Data emisi dari kegiatan tersebut disajikan pada Tabel 5. Menurut penelitian Suhendi (2005), emisi $\mathrm{CO}_{2}$ dari LPG dan minyak tanah rata-rata rumah tangga setiap bulannya adalah 98,84 kg dengan faktor emisi LPG sebesar $3 \mathrm{~kg} \mathrm{CO}_{2} \mathrm{~kg}^{-1}$ dan minyak tanah sebesar 2,5359 $\mathrm{kg} \mathrm{CO}_{2}$ liter ${ }^{-1}$. Perhitungan jumlah $\mathrm{CO}_{2}$ dari konsumsi rumah tangga dalam waktu setahun adalah hasil perkalian dari emisi $\mathrm{CO}_{2}$ rata-rata rumah tangga per bulan dengan dua belas bulan.
Faktor emisi bahan bakar premium menggunakan perhitungan yang digunakan dalam penelitian Wulandari et al. (2013) yaitu sebesar $2,5 \mathrm{~kg} \mathrm{CO}_{2}$ liter $^{-1}$ dan hasil perhitungannya sama dengan cara perhitungan jumlah $\mathrm{CO}_{2}$ yang diemisikan oleh LPG dan minyak tanah.

Rumah tangga yang ada sebagian masih menggunakan minyak tanah sebagai bahan bakar memasak sebaiknya beralih ke LPG pada masa mendatang. Menurut penelitian Suhendi (2005) menunjukkan bahwa total emisi $\mathrm{CO}_{2}$ penggunaan LPG lebih rendah daripada minyak tanah. Pengurangan emisi ini sebaiknya mendapatkan prioritas sebagai upaya mengurangi emisi $\mathrm{CO}_{2}$.

Tabel 5. Data emisi karbon dioksida kegiatan rumah tangga selama setahun

\begin{tabular}{lccc}
\hline Jenis bahan bakar & Jumlah rumah & $\begin{array}{c}\text { Rata-rata emisi } \mathrm{CO}_{2}\left(\mathrm{~kg} \mathrm{rumah}^{-1}\right. \\
\left.\text { bulan }^{-1}\right)^{\mathrm{a}}\end{array}$ & \begin{tabular}{c}
${\mathrm{Jumlah} \mathrm{CO}_{2}}^{\text {(ton) }}$ \\
\hline LPG dan Minyak Tanah
\end{tabular} \\
Premium & 546 & 94,84 & 647,59 \\
\hline Total & 546 & 37,50 & 245,70 \\
\hline
\end{tabular}

Keterangan : ${ }^{a}$ Faktor konversi berdasarkan Suhendi (2005) dan Wulandari et al. (2013)

Pupuk yang digunakan selama kegiatan produksi adalah Urea, RPH, MoP, Kieserit, Dolomit, HGFB, $\mathrm{CuSO}_{4}$, dan $\mathrm{ZnSO}_{4}$. Pada penelitian ini, pupuk yang dihitung jejak karbonnya di lapangan adalah pupuk urea dengan cara mencari jumlah emisi $\mathrm{CO}_{2}$. Pupuk urea yang sudah dikenal mudah menguap ini melepaskan $\mathrm{CO}_{2}$ sebesar $0,733 \mathrm{~kg}$ setiap aplikasi $1 \mathrm{~kg}$ melalui proses hidrolisis (IPCC, 2007). Dengan asumsi, penggunaan pupuk urea selama proses produksi setahun adalah $1.274 .873 \mathrm{~kg}$, maka jumlah $\mathrm{CO}_{2}$ yang dihasilkan adalah 930,65 ton (Tabel 6). Pupuk yang potensial melepaskan emisi setara karbon adalah hanya pupuk Urea dan Dolomit. Nilai emisi langsung pada Dolomit tidak dihitung karena Dolomit termasuk pupuk slow release, sehingga nilai pupuk yang menguap dianggap kecil dan tidak berpengaruh besar terhadap jumlah emisi $\mathrm{CO}_{2}$.

Pengawasan pada saat aplikasi pupuk perlu dipertahankan jika sudah sesuai prosedur dan ditingkatkan jika belum sesuai prosedur perusahaan. Pemupukan yang tidak sesuai prosedur seperti pupuk yang disebar melebihi dosis pada beberapa pohon di bagian awal pemupukan maka akan menyebabkan pohon di bagian belakang tidak mendapatkan dosis yang sesuai. Dosis pupuk pada masing-masing blok ditentukan langsung oleh tim research and development (R\&D) dengan cara melakukan leaf sampling unit (LSU). Pemupukan yang tidak sesuai prosedur dapat menyebabkan pupuk yang menguap semakin besar. Peningkatan penguapan tersebut berimplikasi pada peningkatan jumlah emisi $\mathrm{CO}_{2}$. 
Tabel 6. Data emisi karbon dioksida berdasarkan pupuk selama setahun

\begin{tabular}{|c|c|c|c|c|}
\hline Jenis pupuk & Senyawa kimia & Penggunaan $\left(\mathrm{kg}\right.$ tahun $\left.^{-1}\right)$ & Faktor konversi $\left(\mathrm{CO}_{2} \mathrm{~kg}^{-1}\right)^{\mathrm{a}}$ & $\begin{array}{c}\text { Jumlah CO2 } \\
\text { (ton) }\end{array}$ \\
\hline Urea & $\left(\mathrm{NH}_{2}\right)_{2} \mathrm{CO}$ & 1.274 .873 & 0,73 & 930,65 \\
\hline RPH & $\mathrm{Ca}_{3}\left(\mathrm{PO}_{4}\right)_{2}$ & 806.315 & - & - \\
\hline MoP & $\mathrm{KCl}$ & 1.522 .696 & - & - \\
\hline Kieserit & $\mathrm{MgSO}_{4} \cdot \mathrm{H}_{2} \mathrm{O}$ & 676 & - & - \\
\hline Dolomit & $\mathrm{CaMg}\left(\mathrm{CO}_{3}\right)_{2}$ & 84.095 & - & - \\
\hline HGFB & $\mathrm{Br}$ & 62.947 & - & - \\
\hline $\mathrm{CuSO}_{4}$ & $\mathrm{CuSO}_{4}$ & 22.628 & - & - \\
\hline $\mathrm{ZnSO}_{4}$ & $\mathrm{ZnSO}_{4}$ & 19.415 & - & - \\
\hline Total & - & - & - & 930,65 \\
\hline
\end{tabular}

Keterangan : “_“ dianggap tidak ada emisi $\mathrm{CO}_{2}$; a faktor konversi diperoleh dari IPCC (2007)

Selama proses pengolahan TBS menjadi $\mathrm{CPO}$, pabrik juga mengemisikan $\mathrm{CO}_{2}$ melalui limbahnya. Limbah dari kelapa sawit berupa limbah cair dan padat. Menurut Rahayu et al. (2015) limbah cair pabrik kelapa sawit/ palm oil mill effluent (POME) dari pabrik yang berkapsitas 45 ton setiap jam akan memproduksi limbah cair $600 \mathrm{~m}^{3}$ setiap hari dengan asumsi setiap ton TBS menghasilkan $0,7 \mathrm{~m}^{3}$ atau sekitar 0,67 ton (Lubis dan Widanarko, 2011) limbah cair; dan PKS

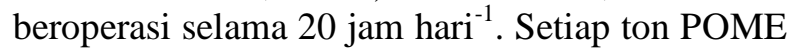
akan mengemisikan $\mathrm{CO}_{2}$ sebesar 19,4 kg ke udara (Vijaya et al., 2010). Produksi TBS selama periode Mei 2015 - April 2016 adalah 95.727.821 $\mathrm{kg}$, maka $\mathrm{CO}_{2}$ yang diemisikan ke udara dari POME adalah 1.244,27 ton.

Karbon $\mathrm{CO}_{2}$ dari limbah cair kelapa sawit berasal dari aktivitas bakteri anaerob yang menghasilkan gas. Bakteri tersebut berfungsi untuk meningkatkan jumlah biological oxygen demand (BOD) menjadi $8.200-55.000 \mathrm{mg} \mathrm{l}^{-1}$ dan chemical oxygen demand (COD) menjadi 15.103 - $65.100 \mathrm{mg} \mathrm{l}^{-1}$ (Deptan, 2006). Bakteri tersebut ditambahkan secara manual agar kadar BOD dapat segera turun hingga pada batas yang aman. Emisi $\mathrm{CO}_{2}$ dari hasil oksidasi penguraian bahan organik limbah kelapa sawit dapat dikurangi dengan cara meningkatkan efisiensi pengolahan TBS, sehingga limbah cair yang dihasilkan menjadi lebih sedikit. Pengurangan limbah cair berdampak baik terhadap pengurangan emisi karbon.

Selain mengemisikan $\mathrm{CO}_{2}$, penguraian limbah cair oleh bakteri anaerob juga menghasilkan gas metan $\mathrm{CH}_{4}$. Gas metan tersebut berpotensi menjadi biogas sumber energi pembangkit listrik (Wibowo, 2015). PKS dengan kapasitas 45 ton jam $^{-1}$ berpotensi menghasilkan listrik sebesar 1 MWe (Rahayu et al., 2015). Listrik hasil konversi tersebut dapat menjadi solusi untuk alternatif sumber tenaga listrik untuk PKS, perkantoran dan perumahan.

\section{Carbon sequestration}

Selama kegiatan produksi minyak kelapa sawit, karbon yang diemisikan juga diserap oleh tanaman kelapa sawit. Carbon sequestration adalah penyerapan karbon yang terjadi secara alami maupun buatan oleh sesuatu pada periode tertentu. Sumber karbon yang diserap dapat berasal dari atmosfer, stok karbon di samudera, lingkungan terestrial (vegetasi, tanah, dan sedimen), atau formasi geologi (USGS, 2008). Menurut penelitian Pulhin et al. (2014), setiap hektar kelapa sawit menyerap karbon sebanyak 6,1 ton atau setara dengan $22,387 \mathrm{CO}_{2}$ e $\operatorname{tahun}^{-1}$ pada kerapatan 55 ton $\mathrm{C}$ ha $^{-1}$. Total serapan karbon PT Surya Intisari Raya Kebun Sei Lukut adalah 97.560,53 ton tahun ${ }^{-1}$ (Tabel 7).

Selama kegiatan penelitian berlangsung, upaya perusahaan untuk meningkatkan serapan karbon $\mathrm{CO}_{2}$ baik itu melalui penanaman pohon atau pengaturan jenis pohon yang sebaiknya ditanam di komplek perumahan karyawan sudah direncanakan. Upaya tersebut juga dilakukan melalui program penghijauan pekarangan masyarakat menggunakan tanaman pekarangan atau tanaman hias. Beberapa tanaman terbukti dapat menyerap beberapa polutan berbahaya, seperti tanaman sansiviera (Rosha et al., 2013).

Tabel 7. Serapan karbon dioksida di kebun Sei Lukut selama setahun

\begin{tabular}{lccc}
\hline Jenis Lahan & Luas (ha) & Serapan $\mathrm{CO}_{2 \mathrm{e}}($ ton ha & -1 \\
Mineral & $2.864,85$ & 22,387 & Total serapan $\mathrm{CO}_{2 \mathrm{e}}$ (ton tahun $\left.^{-1}\right)$ \\
Gambut & $1.493,06$ & 22,387 & $64.135,3970$ \\
\hline Total & $4.357,91$ & & $33.425,1342$ \\
\hline
\end{tabular}

Keterangan : ${ }^{a}$ Faktor konversi menurut Pulhin et al. (2014) 


\section{Perhitungan neraca karbon}

Pabrik kelapa sawit yang ada mengolah TBS menjadi minyak mentah. Minyak mentah hasil olahan dari TBS dapat berupa CPO dan kernel palm oil (KPO). CPO merupakan minyak mentah yang berasal dari hasil pengolahan mesocarp dari buah kelapa sawit, sedangkan KPO merupakan minyak mentah yang didapatkan dari inti biji kelapa sawit. Perusahaan hanya memproduksi minyak mentah CPO. Hasil TBS

Tabel 8. Data produksi TBS dan CPO Kebun Sei Lukut Mei 2015-April 2016

\begin{tabular}{lccc}
\hline Bulan & Produksi TBS $(\mathrm{kg})$ & Rendemen minyak $(\%)$ & CPO (l) \\
\hline Mei '15 & $8.233 .650,00$ & 22,70 & $2.018 .561,63$ \\
Jun '15 & $7.060 .030,00$ & 23,01 & $1.754 .473,94$ \\
Jul '15 & $7.696 .140,00$ & 23,41 & $1.945 .799,68$ \\
Agt '15 & $11.797 .220,00$ & 23,00 & $2.930 .429,45$ \\
Sep '15 & $12.075 .450,00$ & 23,02 & $3.002 .150,08$ \\
Okt'15 & $11.130 .070,00$ & 22,51 & $2.705 .809,06$ \\
Nov '15 & $8.583 .740,00$ & 22,54 & $2.089 .557,00$ \\
Des '15 & $7.533 .100,00$ & 23,11 & $1.880 .171,36$ \\
Jan '16 & $6.370 .860,00$ & 22,56 & $1.552 .249,00$ \\
Feb '16 & $5.857 .803,00$ & 22,81 & $1.443 .058,05$ \\
Mar '16 & $4.691 .308,00$ & 23,05 & $1.167 .854,21$ \\
Apr'16 & $4.698 .443,00$ & 23,00 & $1.167 .093,24$ \\
\hline Total & $95.727 .814,00$ & - & $23.657 .205,00$ \\
\hline Rata-rata & $7.977 .317,83$ & 22,89 & $1.971 .434,00$ \\
\hline
\end{tabular}

Berdasarkan perhitungan neraca karbon yang diserap dengan yang diemisikan, maka selama periode Mei 2015 hingga April 2016, Kebun Sei Lukut mengemisikan karbon dalam bentuk $\mathrm{CO}_{2}$ sebanyak 323.571,04 ton. Bersamaan dengan itu, tanaman kelapa sawit Kebun Sei Lukut juga menyerap karbon $\mathrm{CO}_{2}$ sebanyak 97.560,53 ton $\mathrm{CO}_{2} \mathrm{e}$ atau sebesar 30,15\% dari total $\mathrm{CO}_{2}$ yang diemisikan selama satu tahun. Berdasarkan nilai emisi dan nilai serapan tersebut, maka nilai $\mathrm{CO}_{2}$ yang tidak diserap oleh tanaman adalah 226.010,5 ton (nilai carbon footprint). Nilai carbon footprint $\mathrm{CO}_{2}$ untuk setiap satu liter $\mathrm{CPO}$ adalah $9,55 \mathrm{~kg}$. Nilai tersebut didapatkan dari hasil pembagian antara nilai carbon footprint $\mathrm{CO}_{2}$ yang tidak diserap dengan hasil CPO selama periode satu tahun.

\section{KESIMPULAN}

Setiap liter CPO yang dihasilkan meninggalkan jejak karbon $\mathrm{CO}_{2}$ sebanyak 9,55 $\mathrm{kg}$. Hal tersebut mengindikasikan bahwa kegiatan industri kelapa sawit dalam menghasilkan minyak $\mathrm{CPO}$ mengemisikan $\mathrm{CO}_{2}$. Emisi berasal dari respirasi tanah mineral dan gambut, konsumsi solar, konsumsi listrik, bahan bakar rumah tangga, pemupukan, dan emisi limbah cair kelapa sawit. Emisi $\mathrm{CO}_{2}$ terbesar berasal dari respirasi tanah dan CPO yang didapatkan oleh PKS dari bulan Mei 2015 hingga bulan Juni 2016 adalah 95.727.821 kg dan 23.657.206,71 liter (Tabel 8) dengan rata-rata rendemen $22,89 \%$ bulan $^{-1}$. Menurut Pahan (2008), rendemen yang baik minyak CPO suatu pabrik adalah sekitar $22-25 \%$. Hal tersebut menunjukkan bahwa rendemen minyak kelapa sawit yang dihasilkan oleh perusahaan sudah baik. mineral dan terendah dari penggunaan solar genset yang digunakan untuk sumber tenaga listrik di PKS. Dengan demikian manajemen lahan merupakan hal yang paling mendasar untuk dilakukan dalam rangka menekan emisi karbon dari perkebunan kelapa sawit seperti menjaga kedalaman muka air tanah gambut dan menambah vegetasi penyerap karbon.

\section{UCAPAN TERIMA KASIH}

Terima kasih kepada Manager PT. Surya Intisari Raya-Lukut First Resource Group, Riau yang telah memfasilitasi penelitian ini.

\section{DAFTAR PUSTAKA}

Anggono, T. dan K. Ahadi. 2015. Analisis konsumsi energi listrik pada televisi. Jurnal M\&E. 13(1): 81-87.

Berglund, O. and K. Berglund. 2011. Influence of water table level and soil properties on emissions of greenhouse gases from cultivated peat soil. Journal of Soil Biology \& Biochemistry 43(5): 923-931.

Couwenberg, J., R. Dommain. and H. Joosten, 2009. Greenhouse gas fluxes from 
tropical peatlands in south- east Asia. Journal of Global Change Biology 16(6): 1715-1732.

[DEFRA] Department for Enviroment, Food, and Rural Affairs. 2010. Guidelines to Defra / DECC's GHG Conversion Factors for Company Reporting. [Internet] [diunduh 2016 Oktober 04] Tersedia pada http://www.sthc.co.uk/documents/DEFR A-guidelines-ghg-conversion-factors_201 $0 . p d f$

[Deptan] Departemen Pertanian. 2006. Pedoman pengelolaan limbah industri kelapa sawit. [Internet] [diunduh 2017 Februari 11] Tersedia pada Deptan-2006-PedomanPengelolaan-Limbah-Kelapa-Sawit.pdf

[Ditjenbun] Direktorat Jenderal Perkebunan. 2016. Statistik Kelapa Sawit Indonesia 2014-2016. [Internet] [diunduh 2017 Februari 08] Tersedia pada http://ditjenbun.pertanian.go.id/tinymcpuk /.../2016/SAWIT\%202014-2016. pdf

Evri, M. 2012. Konstruksi carbon footprint sebagai dasar argumentasi kampanye negatif terkait perubahan iklim terhadap industri kelapa sawit Indonesia menuju industri kelapa sawit nasional berkelanjutan. BPPT Jakarta.

Hadiwijaya, B., B. Septiwibowo and J. Caliman. 2014. Ecosystem $\mathrm{CO}_{2}$ exchange assessment of oil palm plantation on mineral soil. [Internet] [diunduh 2016 Oktober 25] Tersedia pada http://icopeseries.com/2014-oral-abstract/07\%20-\% 20TS03b\%20BramICOPE\%202014v02 .pdf.

Hirano, T., H. Segah, K. Kusin, S. Limin, H. Takashi dan M. Okasi. 2012. Effects on disturbances on carbon balance of tropical peat swamp forest. Journal of Global Change Biology. 18(11): 3410-3422.

Hooijer, A., S. Page, J. Jauhiainen, W.A. Lee, X.X. Lu, A. Idris and G. Anshari. 2012. Subsidence and carbon loss in drained tropical peatlands. Journal of Biogeoscience 9: 1053-1071.

Indofood Agri Resources LTD. 2014. Sustainability report. [Internet] [diunduh
2016 Oktober 25] Tersedia pada www.indofoodagri.com.

[IPCC] Intergovermental Panel on Climate Change. 2007. Technical Summary. In: Climate Change 2007: ThePhysical Science Basis. Contribution of Working Group I to the Fourth Assesment Report of the Intergovermental Panel on Climate Change [Solomon, S., Qin, D., Manning, M., Chen, Z., Marquis, M. Averyt, K.B., Thingor, $M$ and Miller H.L. (eds)]. Cambridge University Press, Cambridge, United Kingdom and New York, NY, USA.

Kementerian Lingkungan Hidup. 2012. Pedoman penyelenggaraan inventarisasi gas rumah kaca nasional. [Internet] [diunduh 2016 November 07] Tersedia pada www.menlhk.go.id/.

Lubis, R.E. dan A. Widanarko. 2011. Buku Pintar Kelapa Sawit. Jakarta (ID): AgroMedia Pustaka.

Nugraha, B.S. dan J. Suprianto. 2007. Aplikasi teknologi injeksi bahan bakar elektronik (EFI) untuk mengurangi emisi gas buang sepeda motor. Jurnal Ilmiah Populer dan Teknologi Terapan. 5(2): 692-706.

Nusantara, R.W., Sudarmadji, T.S. Djohan dan E. Haryono. 2014. Emisi $\mathrm{CO}_{2}$ tanah akibat alih fungsi lahan hutan rawa gambut di Kalimantan Barat. Jurnal Manusia dan Lingkungan. 21(3): 268-276.

Ojanen, P., K. Minkkinen and T. Penttila. 2013. The current greenhouse gas impact of forest drained Boreal peatland. Journal of Forest Ecology and Management. 289: 201-208.

Page, S.E., J.O. Rieley and C.J. Banks. 2010. Global and regional importance of the tropical peatland carbon pool. Journal of Global Change Biology. 17(2): 798-818

Pahan, I. 2008. Panduan Lengkap Kelapa Sawit. Jakarta (ID): Penebar Swadaya.

Palaloi, S. 2014. Analisis penggunaan energi listrik pada pelanggan rumah tangga kapasitas kontrak daya 450 VA. Prosiding Seminar Nasional Aplikasi Sains \& 
Teknologi (SNAST) 2014. Yogyakarta, 15 November 2014.

Pulhin, F.B., Lasco R.D. and Urquiola J.P. 2014. Carbon sequestration potential of oil palm in Bohol, Philipines. Journal of Ecosystem \& Development. 4(2): 14-19.

Rahayu, A.S., D. Kariswulan, Yuwono, I. Trisnawati, S. Mulyasari, S. Hokermin, dan V. Paramita. 2015. Buku Panduan Konversi POME Menjadi Biogas. Winrock Internasional. Arkansas.

Rosha, P.T., M.N. Fitriayana, S.F. Ulfa dan Dharminto. 2013. Pemanfaatan Sansiviera tanaman hias penyerap polutan sebagai upaya mengurangi pencemaran udara di Kota Semarang. Jurnal Ilmiah Mahasiswa 3(1): 1-6.

Setyamidjaja D. 2006. Kelapa Sawit: Tehnik Budi Daya, Panen, dan Pengolahan. Yogyakarta (ID): Kanisus.

Sugiyanto. 2013. Jejak karbon di pertanian dan produk pertanian. Direktorat Perlindungan Perkebunan Kementerian Pertanian. [Internet] [diunduh 2015 Desember 10] Tersedia pada ditjenbun.pertanian.go.id.

Suhendi, F. 2005. Emisi $\mathrm{CO}_{2}$ dari konsumsi domestik. [Internet] [diunduh 2017 Januari 05] Tersedia pada Sim.nilim.go.jp/ge/semi6/paper/06-fen.d $o c$.
[USGS] United State Geological Survey. 2008. Carbon sequestration to mitigate climate change. [Internet] [diunduh 2017 Februari 09] Tersedia pada https://pubs.usgs.gov/fs/2008/3097/pdf/C arbonFS.pdf.

Vijaya, S., A.N. Ma and Y.M. Choo. 2010. Capturing biogas: A means to reduce greenhouse gas emissions for the production of crude palm oil. American Journal of Geoscience 1(1): 1-6.

Widhi, A.K.P. dan J. Hermana. 2013. Analisis pengurangan emisi $\mathrm{CO}_{2}$ melalui manajemen penggunaan listrik dan ketersediaan ruang terbuka hijau di gedung perkantoran pemerintah Kota Surabaya. Jurnal Teknik Pomits 2(3): 214-217.

Winarna, K. Murtilaksono, S. Sabiham, A. Sutandi, and S.S. Sutarda. 2015. Effect of ground water level and steel slag application on soil moisture variability and actual hydrophobicity of peat soil in oil palm plantation. Journal of Agronomy. 14(1): $15-22$.

Wulandari M T., Hermawan dan Purwanto. 2013. Kajian emisi $\mathrm{CO}_{2}$ berdasarkan penggunaan energi rumah tangga sebagai penyebab pemanasan global. Pp. 434-440. Dalam prosiding Seminar Nasional Pengelolaan Sumberdaya Alam dan Lingkungan. Semarang, UNDIP 10 September 2013. 